\title{
The People, Populism, and The Leader's Semi-Embodied Power
}

\author{
Carlos DE LA TORRE \\ University of Kentucky
}

Political theorist Sofia Näström reminds us that "the people" is "one of the more used and abused concepts in the history of politics"1. Perhaps its vagueness, the fact that it can be given alternative and even contradictory meanings, explains why it could be used so efficiently as a mobilizing tool. This category is central for conceptions of democracy, nationalism, and populism. Yet it is difficult to point out who the people are. Contrary to assertions of politicians, activists, and some folklorists, "the people" is not a primary datum ${ }^{2}$. It is not there, waiting for someone to discover its essence, or for someone to represent or to embody its interests. The people is foremost a discursive construct, and a claim made in struggles between politicians, activists, and intellectuals.

The people like Janus has two faces: "it menaces the political order at the same time that grounds it"3. The concept of the people is still used, as in earlier times, to refer to the threat of dangerous mobs that could be mobilized by demagogues. Hegel "argued that talking about the people as the ultimate source of institutions and procedures merely gives political charlatans and nationalist demagogues an empty phrase with


of the dangerous masses by constructing the people as inherently virtuous, and rightful. They imagine the people as a "mythic being that is not only the source of political legitimacy, but can sometimes appear to redeem politics from oppression, corruption, and banality" .

Given its vagueness, it is not a surprise that Frederick Engels "reacted brusquely to a reference to 'the people in general' in the 1891 Erfurt Programme, asking 'what is that?" Can the people speak, and if so how does it talk? Does it speak by voicing individual preferences that can be counted in public opinion polls, and as individual votes? Can the people speak with one voice when they rebel to demand their recognition? Who speaks for the people? Who has the power to speak about the people? ${ }^{7}$

1. Sofia NÄStRÖM, “The Legitimacy of the People”, Political Theory, 35/3 (2007), p. 324.

2. Ernesto LaClau, On Populist Reason, London and New York, Verso, 2005, p. 224; Ernesto LACLAU "Populism: What's in a name?", in Francisco PANIzZA (ed.), Populism and the Mirror of Democracy, London, Verso, 2005, p. 48.

3. Pierre Rosanvallon, Democracy Past and Future, edited by Samuel Moyn, New York, Columbia University Press, 2006, pp. 84-85.

4. Bernard YACK, "Popular Sovereignty and Nationalism”, Political Theory, 29/4 (2001), p. 521.

5. Margaret CAnovan, The People, Cambridge, Polity Press, 2005, p. 123.

6. Alan KNIGHT, "Populism and Neopopulism in Latin America. Especially Mexico", Journal of Latin American Studies, 30/2 (1998), p. 226.

7. Pierre Bourdieu, "The Uses of "The People"” In Other Words. Essays Towards a Reflexive Sociology, Stanford, Stanford University Press, 1990, p. 150. 
Using examples of leftwing populists discourses from Hugo Chávez in Venezuela, Evo Morales in Bolivia, and Rafael Correa in Ecuador, this paper analyzes the ambiguous meanings of the concepts of "the people" and populism. It illustrates how these concepts oscillate between poles: whole and part, active and passive, threat and promise. It analyzes debates about who are the people, who speaks on their behalf, and what are their relations with democratic ideals. The first section analyzes how the external and internal boundaries of the people are constructed. It explains how the concept of populism inherited views of the people as a danger to democracy. The second focuses on attempts to give recognition to those considered as not having a voice, "those who have no part", "who do not count", "who have no entitlement to exercise their power" $"$. The third studies the different images of the two bodies of the people. The next analyzes the conceptions of democracy that ground constructions of the people as individual actors of everyday politics, and as the eschatological savior of democracy. The fifth explores different attempts to speak for the people, and to represent or to embody its will and interests.

\section{The boundaries of the people}

A "people" is defined in contrast to other peoples. Bernard Yack reminds how British patriots defined themselves in opposition to those "garlic-eating" Catholics across the Channel ${ }^{9}$. Narratives of peoplehood, Rogers Smith writes, combine economic stories, political power stories, and constitutive narratives ${ }^{10}$. The later focus on the member's race, ethnicity, religion, history, and culture that is constitutive of their identities. These narratives that integrate appeals to reason and to emotions are the foundation for projects of people building.

Narratives of peoplehood do not only define an US in opposition to external boundaries, they also include and exclude those who are the rightful and moral members of national communities. The people need to be constantly redefined and purified. Members are included and excluded according to criteria such as culture, "language, blood, and territory" 11 . Rogers Smith shows how the US was imagined as a white nation that included all European immigrants, excluding those racialized as nonwhite Others. The legacies of white supremacist images of the US continue to inform the self-understanding of the extreme right. The impossibility of accepting an African American as president encouraged sectors of the right to get involved in what is known as the Tea Party.

In Latin America narratives of mestizaje -understood as cultural and ethnic mixing- were used to exclude indigenous people, while simultaneously inviting them to belong to the nation on the condition that they abandoned their cultural specificity. Indigenous movements in Latin America rejected the politics of mestizaje, demanding

8. Jacques Ranclère, Dissensus. On Politics and Aesthetics, New York and London, Continuum, 2010, pp. 32-33.

9. YACK, "Popular Sovereignty and Nationalism", p. 525.

10. Rogers SмIтH, "Citizenship and the Politics of People-Building”, Citizenship Studies, 5/1 (2001), pp. 73-96.

11. Giorgio Agamben, "What is a People?", in Means Without End. Note on Politics, Minneapolis, University of Minnesota Press, 2000, p. 31. 
their socioeconomic and cultural inclusion and recognition. Evo Morales, the first indigenous president of Bolivia, is carrying out what his regime describes as a decolonizing revolution. Yet, it remains ambiguous what does the Morales' regime mean by decolonization, who makes the plural people of Bolivia, and who speaks for the people. For example, Morales recognizes the worth of indigenous people when his discourses portrait them as the embodiment of national values. Yet, when indigenous people challenge his policies, as when they opposed the building of roads in the TIPNIS National Park, they are stigmatized as enemies of the nation.

Elites linked the people to the mob. The images of "the dangerous mass" inherited from Crowd Psychology and Mass Society theories continue to inform popular and academic descriptions about the menace of the rabble. The mob is feared because it is seen as irrational, and as a danger to civility. It brings the specters of disorganization, and anomie. So ingrained are the fears of the mob, that one of the common meanings of the term "pueblo" in Spanish refers to the wretched, the oppressed, the un-ruled, and uncivilized.

In Latin America elites continue to view the unruly and mostly nonwhite pueblo as the mob. In Venezuela the opposition appropriated the term "civil society" for their organizations made up of people of relatively privileged ethnic and class backgrounds. They portrayed themselves as rational, democratic, and organized citizens, the true embodiment of the democratic and rational people. Using long-held views of the poor, the privately owned media constructed Chávez's followers as primitive and uncivilized mobs, and as the antithesis of the rational and democratic pueblo. As Luis Duno Gottberg shows the media racialized Chávez's followers with images that painted them as the embodiment of barbarism and as threat to civil and democratic society ${ }^{12}$.

After the introduction of structural adjustment policies under Carlos Andrés Pérez's second administration (1989-93) populist followers were transformed into "barbaric masses" The hike in the price of domestic gasoline in 1989, Fernando Coronil argues, broke the bond between the paternalistic state and the people based on the shared assumption of the birthright of all Venezuelans for oil rents. Massive demonstrations turned into two days of "massive rioting and looting, escalating from neighborhood groceries stores to commercial centers in Caracas and other cities"13. After these events poor people were transformed into "an unruly and parasitical mass to be disciplined by the state and made productive by the market"14. This rebellion named as the Caracazo conveyed elite nightmares of the savage, uncivilized, disorganized rabble that invaded the centers of civility. These constructions of the rabble as the antithesis to reason and civilized behavior allowed or justified state fierce and brutal repression that ended in at least 400 deaths.

Elites sometimes use paternalistic arguments to depict their mission as the duty to transform the unruly mob (el pueblo) into civilized and educated citizens of their nations. When the poor, the nonwhite, and the excluded accept the paternalistic embrace of their elites they are not feared. They are protected and treated with maternal and

12. Luis Duno GotTberg, "The Color of Mobs: Racial Politics, Ethnopopulism, and Representation in the Chávez Era", in Davil Smilde and Daniel Hellinger (eds.), Venezuela's Bolivarian Democracy, Durham, Duke University Press, 2011, pp. 271-298.

13. Fernando Coronil, The Magical State, Chicago and London, The University of Chicago Press, 1997, p. 376.

14. Ibid., p. 378 . 
paternal love. But when the excluded and marginalized rebel or riot, as in Venezuela during the Caracazo, they are stigmatized as a threat, and are imagined as an irrational force that needs to be contained by any means necessary.

Elites construct the excluded as incapable of rational speech. "If there is someone you do not wish to recognize as a political being, Rancière writes, you begin by not seeing him as the bearer of signs of politicity, by not understanding what he says, by not hearing what issues from his mouth as discourse" ${ }^{\text {"15 }}$. Exclusions are based on symbolic configurations of ways of speaking, seeing, and acting. "The Roman patrician power refused to accept that the sounds uttered from the mouths of the plebeians were speech $^{16}$. Differently from rational citizens who deliberate in the public sphere, and participate in the institutions of liberal democracy, the mob is considered to act irrationally. They riot to destroy, to loot, and to kill. Contrary to citizens, who reason their political preferences, and vote on behalf of political platforms, the people when viewed as the mob follow their emotions. Plebiscitary democracy based on the manipulation of emotions by demagogues is the antagonist, it is argued, of democracy based on reason.

The concept of populism in Latin America was built around images of the irrational mob. Gino Germani, an Italian born sociologist who migrated to Argentina to escape from Mussolini's jail and who witnessed the birth of Juan Perón's populist movement in the 1940s, interpreted it as an example of working class totalitarianism. For Germani populism was a phase in Latin America's history linked to the transition from a traditional to a modern society. Rapid and abrupt structural change caused by urbanization and industrialization created masses in a state of anomie. Perón is portrayed as a charismatic leader who appealed to the emotions of these irrational masses to get to power and to govern. Even though Perón's populism was democratizing in so far as it incorporated previously excluded masses into political life, it had authoritarian traits. Peronism, Germani wrote, "gave workers an experience of political and social participation in their personal lives, annulling at the same time political organizations and the basic rights that are the pillars for any genuine democracy"17.

Since Germani's seminal essays, Latin American scholars have debated on whether populism is a phase in the history of the region, whether it is irrational or not, and on whether it is a threat or a corrective for liberal democracy ${ }^{18}$. Most scholars no longer link populism to pathologies such as the irrationality of the masses, or to the manipulation of powerful charismatic charlatans. Populism is conceptualized as a discourse and/or as a political strategy. Populism is based on a discourse that pits the people and the elites as antagonistic poles. It is based on a moral and even religious

15. RANCIERE, Dissensus, p. 38.

16. Jacques RAnCIÈRE, Staging the People. The Proletariat and His Double, New York, Verso, 2011, p. 37.

17. Gino Germani, "La Integración de las masas a la vida política y el totalitarismo", in Política y Sociedad en una Época de Transición, Buenos Aires, Paidós, 1971 (originally published in 1956), p. 337.

18. Carlos DE LA Torre and Cynthia J. ARnson, "The Evolution of Latin American Populism and the Debates Over its Meaning", in Id., Latin American Populism in the Twenty First Century, Baltimore and Washington, The Johns Hopkins University and the Woodrow Wilson Center Press, 2013, pp. 1-44. 
Manichean worldview ${ }^{19}$. Populism is also a political strategy to achieve power and to govern allegedly on behalf of the people, bypassing existing institutions ${ }^{20}$. According to Weyland's influential definition, populism is a political strategy for winning and exercising power based on the direct, unmediated, non-institutionalized support of large numbers of followers.

The conceptions of the people of most Latin American populists seek to empower (politically, economically, and culturally) excluded segments of the population. Chávez rhetoric, for example, politicized relations of inequality between different classes and ethnic groups. He reclaimed Venezuela's indigenous and black heritages that were downplayed by the Punto Fijo white elites during Venezuela's pacted democracy ${ }^{21}$. Chávez tapped into the "deep reservoir of daily humiliation and anger felt by people of the lower classes",22. On the one hand, Chávez's populist mobilization activated and incorporated previously excluded people. But, on the other, he co-opted or reduced the autonomy of organizations of civil society. This is why as in other populist experiences there are collusions between attempts of top down mobilization and responses and demands from the grass roots that go beyond the intentions of their leaders.

\section{The Virtuous and Mythical People of Populism}

Scholars and activists challenge images of the dangerous mob portraying the people as the mythical bearer of virtue. Jules Michelet, the historian of the French Revolution, exalted the people as the "embodiment of two treasures: the first is the virtue of sacrifice, and the second are instinctual ways of life that are more precious that the sophisticated knowledge of the so-called cultured men"23. Mikhail Bakunin wrote:

19. José Álvarez Junco, El Emperador del Paralelo. Lerroux y la Demagogia Populista, Madrid, Alianza Editorial, 1990; Carlos DE LA TORRE, Populist Seduction in Latin America, Athens, Ohio University Press, 2010 (second edition); Kirk HAWKINS, Venezuelas' Chavismo and Populism in Comparative Perspective, Cambridge, Cambridge University Press, 2010; Alan KNIGHT, "Populism and Neopopulism in Latin America, especially Mexico"; Cas MudDE, "The Populist Zeitgeist", Government and Opposition, 39/4 (2004), pp. 541-563; Cas MudDE and Cristóbal Rovira Kaltwasser (eds.), Populism in Europe and the Americas Threat or Corrective for Democracy?, Cambridge, Cambridge University Press, 2012; PANIZZA, "Introduction: Populism and the Mirror of Democracy", in Francisco PanizZA (ed.), Populism and the Mirror of Democracy, London, Verso, 2005, pp. 1-32; Cristóbal Rovira KALTwASSER, "The Ambivalence of Populism: Threat or Corrective for Democracy", Democratization (2011), pp. 1-25.

20. Kenneth Roberts, "Neoliberalism and the Transformation of Populism in Latin America. The Peruvian Case", World Politics, 48 (October 1995), pp. 82-116; Kurt WEYLAND, "Clarifying a Contested Concept. Populism in the Study of Latin American Politics", Comparative Politics, vol. 34/1 (2001), pp. $1-22$.

21. Julia BuXTON, “The Bolivarian Revolution as Venezuela's Post-crisis Alternative” in Jean GRUGEL and Pía Riggirirozzi (ed.), Governance After Neoliberalism in Latin America., New York, Palgrave, 2009, p. 161.

22. Sujatha Fernandes, Who Can Stop the Drums? Urban Social Movements in Chávez's Venezuela, Durham and London, 2010, p. 85.

23. José Álvarez Junco, "Magia y Ética en la Retórica Política", in José Álvarez Junco (ed.), Populismo, Caudillaje y Discurso Demagógico, Madrid, Centro de investigaciones Sociológicas, 1987, p. 251. 
"the people is the only source of moral truth [...] and I have in mind the scoundrel, the dregs, uncontaminated by bourgeois civilization" 24 .

Populism is a politics of cultural and symbolic recognition of the despised under classes $^{25}$. Populist discourse transforms the humiliations that the rabble, the uncultured, the unseen, and those who have no voice have to endure in their daily life into sources of dignity and even redemption. Paraphrasing Rancière, "it consists in making what was unseen visible, in making what was audible as mere noise heard as speech" ${ }^{26}$. Those who are excluded and stigmatized with administrative categories such as "the poor", "the informal", and "the marginal" become "the people" conceived as the incarnation of all virtue. And those who constantly humiliate them become the hideous elites.

Populist politicians are famous for turning the stigmas of the people into virtues. Juan and Eva Perón transformed the shirtless masses despised by the elites into the embodiment of the Argentinean nation. ${ }^{27}$ The feared rabble became the "beloved rabble" of Colombian populist Jorge Eliecer Gaitán. ${ }^{28}$ When his followers were depicted as a bunch of "whores and criminals", Ecuadorian populist Abdalá Bucaram responded: "the marihuana user, criminal, and whore is the Ecuadorian oligarchy"29.

The people is embodied in a leader. In a message to the National Assembly in 2003, the late Hugo Chávez said: "I am not myself, I am the people". In another occasion he asserted: "this is not about Hugo Chávez this is about a people" ${ }^{\text {" }}$. Under the populist imaginary the people does not face political adversaries but sinful enemies. Hugo Chávez, for example, 'constantly separates the 'people,' the 'true' patriots, from the 'oligarchy', those self-serving elites who work against the homeland. During the general strike called by the opposition [in 2001], Chavez declared, 'this is not about the pro-Chavez against the anti-Chavez [...] but [...] the patriots against the enemies of the homeland" "31. Enemies are constructed with a moralistic logic as not "sharing a common symbolic space within which the conflict takes place" 32 . Differently from adversaries who fight according to a shared set of rules, and whose positions could be accepted, enemies represent an evil threat that must be eradicated.

Populist rhetoric assembles all social, economic, cultural, and ethnic differentiations and oppressions into two irreconcilable poles: the pure people versus evil and rotten elites. The notion of "the people" incorporates the idea of antagonistic

\section{Ibid., p. 253.}

25. Francisco PanizZA, "What Do We Mean When We Talk About Populism?", in Carlos DE LA TORRE and Cynthia Arnson (eds.), Latin American Populism in the Twenty First Century, Baltimore and Washington, The Johns Hopkins University and the Woodrow Wilson Center Press, 2013.

26. RANCIÈRE, Dissensus, p. 38.

27. Daniel JAmes, Resistance and Integration: Peronism and the Argentine Working Class, 1946-1976, Cambridge: Cambridge University Press, 1988.

28 .Herbert Braun, The Assassination of Gaitán: Public Life and Urban Violence in Colombia, Chicago : University of Chicago Press, 1985.

29. De la Torre, Populist Seduction in Latin America, pp. 80-118.

30. José Pedro ZúQuete, "The Missionary Politics of Hugo Chavez," Latin American Politics and Society, 50/ 1 (2008), p. 100-104.

31. Ibid., p. 105.

32. Chantal Mouffe, On the Political, London, Routledge, 2005, p. 20. 
conflict between two groups, with the romantic view of the purity of the people. As a result, "the people" of populism has been imagined as an undifferentiated, unified, fixed, and homogenous entity ${ }^{33}$. The populist image of the people is fixed in time, the will of the people is conceived as transparent, so to speak, especially when they resist and challenge the symbolic, economic, and political domination of the oligarchy. But as Paulina Ochoa argues the people is a process, it is an unfolding series of events. "The people is always under construction and for this reason its will is also incomplete"

Liberals construct "the people", Ochoa argues with criteria of self-limitation. They view the people as indeterminate, accept the view that the will of the people can and probably will change, and for this reason "their appeal to the people's will is fallible, temporary, and incomplete." The people of populism is conceived as inherently right, the voice of the people is always indefeasible, and populists do not accept limitations on their claims to be the authentic and truthful voice of the people.

Rafael Correa who holds a US Ph.D. in economics combines technocratic with populist discourses. Different from liberal views of self-limitation Correa sees himself as having a mission: to lead a "citizen's revolution" to achieve the second and definitive liberation of his motherland. He claims that like the founding fathers, "We are ready to risk our lives to bring change" 35 . The second liberation that Correa is leading is part of a continental wide movement. He ends his speeches quoting Che Guevara's famous words "till victory forever!" In front of an audience of policemen he said: "Nobody takes a step backwards. This revolution will not be sold nor will surrender" 36 . He legitimizes his government with understandings of revolution "as a radical, profound and rapid transformation of political, social and economic structures" 37 . Politics for Correa is not based on consensus. Rather it is viewed as a struggle to reach the liberation of the motherland. He claimed that his revolution "is irreversible, and nobody would stop it",38.

Correa sees himself as the only voice that can speak on behalf of "the people." Dissent, even from the left, is portrayed as treason. He is not just the voice of "people," he also acts as if he embodies their unitary will and interests. The people's trust in his leadership is reiterated in all the elections he has won. Electoral triumphs and carrying social policies on behalf of the poor transformed him into the new liberator. Social movement organizations that are critical to his policies are portrayed as representing the interests of the oligarchy and of the old regime controlled by corrupt political parties, and corporatist interest groups. He called environmentalists who challenged his extractivist policies aniñaditos (well-to-do, infantile and pampered children lacking

33. Leonardo Avritzer, Democracy and the Public Sphere in Latin America, Princeton, Princeton University Press, 2002, p. 72.

34. See also: Paulina OchoA, The Time of Popular Sovereignty. Process and the Democratic State, University Park Pennsylvania, The Pennsylvania State University Press, 2011.

35. Rafael Correa "Discurso de Posesión del Presidente de la República, Economista Rafael Correa", Quito, 10 de agosto 2009.

36. Rafael Correa, "Intervención Presidencial en el Acto de Entrega de Armas en el Comando Provincial de Manabí”, Portoviejo, 12 de marzo 2009.

37. Rafael CORREA "Experiencia de un Cristiano de Izquierda en un Mundo secular" Oxford Union Society, 26 de octubre 2009.

38. Rafael CORREA "Discurso de Posesión del Presidente de la República, Economista, Rafael Correa", Quito, 10 de agosto 2009. 
proper masculinity) "with full belies who oppose everything all the time". He contended that "infantile radical" ecologists are "the main danger to our project". A few months later he corroborated: "We always said that the main danger to our political project, after defeating the right in elections, are the infantile left, environmentalists, and indigenists". ${ }^{39}$ In October 2009, in the midst of a conflict over water usage, he called the leadership of the indigenous organization Confederation of Indigenous Nationalities of Ecuador (CONAIE), "golden ponchos" and "Indian Whigs" out of touch with their social base.

Religious images are often used to represent essentialist narratives of the people. The Christian story of paradise lost-sin-redemption epitomizes the saga of the people, the proletariat, the indigenous, or the nation. An idyllic and free of domination past was lost due to the imposition of alien cultural and economic systems. The role of the liberator is to free the people from suffering in order to let their true and uncorrupted essence to flourish again. The advent of the left wing leader of the coca growers union Evo Morales to the presidency of Bolivia in 2006 was linked to the Pachakuti, "the founding event or break in historical time in which an unjust world is destroyed and a new one is born, renovated, and redeemed" 40 . The new Bolivian Constitution aimed to refound the nation, decolonize Bolivian society, and to establish indigenous communitarian democracy. Some members of Morales government conceived of his regime as the beginning of the end of colonialism, capitalism, and bourgeois representative democracy. Bolivia's Minister of Foreign Relations David Choquehuanca argued that Bolivia that was living under the "age of darkness" is moving towards communitarianism understood as the end of hatred and capitalism, and the beginning of love $\mathrm{e}^{41}$.

The mythical and essentialist constructions of the people, that are a response to the stigmas ascribed to them by elites, might restore the dignity of those constructed as having no voice. Yet these mythical interpretations, even in cases where the people refer to the excluded, could have authoritarian undertones, as illustrated by how Correa labels his leftist opponents as the main danger to the revolution. The image of the indigenous people under Evo Morales government while inclusionary also excludes indigenous people who oppose policies of his administration such as the construction of roads in indigenous territories.

In their effort to give a voice to those who do not have a voice, populists might open the door for authoritarian fantasies. If the people is assumed to be homogeneous, if images of the people do not acknowledge the internal divisions of the people and society, the danger is the creation of an image of the People as One ${ }^{42}$.

39. Rafael CORREA “Informe a la Nación en el Inicio del Tercer Año de Revolución Ciudadana”. Quito, 19 de enero 2009.

40. Charles Lindholm and Pedro José ZúQuete, The Struggle for the World. Liberation Movements for the 21st Century, Stanford, Stanford University Press, 2010, p. 40.

41. Mabel AzCUI, "Bolivia anuncia una nueva era sin capitalismo ni Coca Cola", El País, 1 de agosto de 2012, <http://internacional.elpais.com/internacional/2012/08/01/actualidad/1343840750_594247.html> (consulted -3-24-2013).

42. Claude Lefort, The Political Forms of Modern Society. Bureaucracy, Democracy, Totalitarianism, edited and introduced by John B. Thompson, Cambridge, The MIT Press, 1986. 


\section{The Bodies of the People}

Inspired by Kantarowicz's seminal book, The King's Two Bodies, scholars write about the people's two bodies ${ }^{43}$. "The people" is individual and collective, active and passive, whole and part, the despised mob and the redeeming People that on occasions rise up in unison against injustices. According to Kantarowicz, the King like God was "omnipresent, for in himself he constituted the 'body politic' over which he ruled. But like his son whom God send to redeem mankind, he was man as well as God; he had a 'body natural' as well as his body politic, and the two were inseparable like the persons of the Trinity"44. Edmund Morgan writes that the fiction of the divine rights of kings, however dubious his divinity might seem, did not have to be imagined. "He was a visible presence, wearing his crown and carrying his specter" ${ }^{\prime 2}$. The king's body was mortal and time bound, as well as immortal and eternal. It was imagined as individual as well as collective.

Different from the king, who had a corporeal body, "the very existence of such a thing as the people, capable of acting to empower, define, and limit a previously nonexistent government required a suspension of disbelief ${ }^{\prime 46}$.

\section{The people are never visible at such. Before we ascribe sovereignty to the people we have to imagine that there is such a thing, something we personify as though it were a single body, capable of thinking, of acting, of making decisions and carrying them out, something quite apart from government, superior to government, and able to alter or remove a government at will, a collective entity more powerful and less fallible than a king or that an individual within it or any group of individual it singles out to govern ${ }^{47}$.}

Once the immortal body of the king and the body of the politic was decapitated during the revolutions of the $18^{\text {th }}$ century, the space occupied by the religious political body of the king was opened. Claude Lefort wrote that power was no longer linked to a body: "Power appears as an empty place and those who exercise it as merely mortals who occupy it only temporarily or who could install themselves in it only by force or cunning" ${ }^{48}$. Under democracy, the people of today are not necessarily the people of tomorrow, as the power of today is not the power of tomorrow ${ }^{49}$. Under democracy the image of the people "remains indeterminate".

The uncertainty of democracy where power belongs to the people in abstract, but not to a concrete individual who at the most could occupy it temporarily, could lead to the destruction of democracy. According to Claude Lefort, the revolutions of the $18^{\text {th }}$ century also generated "from the outset the principle that would threaten the emptiness of that space: popular sovereignty in the sense of a subject incarnated in a group,

43. Edmund Morgan, Inventing the People. The Rise of Popular Sovereignty in England and America, New York, W.W. Norton \& Company, 1988; Sheldon S. Wolin, "The People's Two Bodies", Democracy, 1/1 (1981), pp. 9-24; Coronil, The Magical State; Rosanvallon, Democracy Past and Future; YACK, "Popular Sovereignty and Nationalism"; AGAMBEN, "What is a People?", pp. 28-34.

44. MORGAN, Inventing the People., p. 17.

45. Ibid., p. 153.

46. Ibid., p. 58.

47. Ibid., p. 153.

48. LEFORT, The Political Forms of Modern Society., p. 303.

49. Pierre Rosanvallon, "The Test of the Political: A Conversation with Claude Lefort", Constellations, 19/1 (2012), p. 9. 
however extensive, a stratum however poor, and institution or a person, however popular" ${ }^{\prime 50}$. Totalitarianism thus "appears as a forced attempt, a crazed attempt to fill up, even to saturate the empty place" ". Symbolically this is done by abandoning the democratic imagination of the people as "heterogeneous, multiple, and in conflict" and where power does not belong to no one with the image of the People-as-One that denies that division is constitutive of society ${ }^{52}$. Under totalitarianism there are no internal divisions of the people. The divide is between the people, imagined as having one identity and one will, with its external enemies that need to be eliminated in order to maintain the healthy body of the people.

Lefort conceives that democracy and totalitarianism are opposites. He does not analyze the gradations between the extremes of total emptiness and embodiment ${ }^{53}$. Nor does he differentiate between totalitarian projects and regimes ${ }^{54}$. Totalitarian projects might be resisted by civil society and might not end up in totalitarian regimes. Populism lay between democracy and totalitarianism. Differently from totalitarianism, under populism power is not embodied permanently in the proletariat, the nation, the party, or the Egocrat. Political theorist Isidoro Cheresky argues that power under populism is semi-embodied (semi-encarnado) because populists claim legitimacy in wining open and free elections that they could conceivably loose, and they might be bound by electoral results ${ }^{55}$. Yet, because populists simultaneously assume that they embody the will of the people, that the will of the people is always right, and that they are fighting against hideous elites, they might have a hard time accepting that they could lose popular elections. Paulina Ochoa writes that, for López Obrador, "the people is always right, and thus it can have only one unified voice and will. This means that, in his view, it was 'morally impossible' that the opposition could win".

Similarly, Chávez, Correa, and Morales view elections as the ultimate expression of the people's will. Their democratic credentials are grounded in wining open and clean elections, that in theory they could lose. Participating in elections opens the possibility of their defeat, and hence these leaders skewed the electoral playing field. Incumbents are given extraordinary advantages such as using the media, selectively silencing the privately owned media, selectively harassing the opposition, controlling electoral tribunal boards and all instances of appeal, and using massive public investment before the election. When Chávez, Morales, and Correa won elections the process of voting was clean, but the electoral process blatantly favored incumbents. For instance, before the elections of October 2012, Chávez massively increased social spending, launched new missions that focused on housing, social security benefits for those who were not part of the system, and cash transfers for the children of adolescent parents. ${ }^{56}$ Differently from Correa who has been campaigning since he became

50. Andrew ARATo, “Lefort, the Philosopher of 1989”, Constellations, 19/1 (2012), p. 23.

51. Rosanvallon, “The Test of the Political: A Conversation with Claude Lefort”, p. 11.

52. LEFORT, The Political Forms of Modern Society., p. 297.

53. LaClau, On Populist Reason, p. 166.

54. ARATO, "Lefort, the Philosopher of 1989", p. 28.

55. Isidoro CHERESKY, "Mutación democrática, otra ciudadanía, otras representaciones", in Isidoro Cheresky (ed.), ¿Qué Democracia en América Latina?, Buenos Aires, CLACSO Prometeo, 2012, p. 33.

56. Margarita LóPeZ MAYA and Luis LANDER, 'las elecciones de octubre del 2012 en Venezuela y el Debate de la democracia en América Latina’ unpublished document, 2012. 
president in 2007, the opposition only had 42 days to campaign during the February 2013 elections. Correa used televised broadcasts, that all stations are force to transmit, for instance to challenge media reports that his running mate Jorge Glass plagiarized his college thesis from the internet. The government used state media outlets to broadcast live from Correa's campaign trail. According to Participación Ciudadana, a NGO that monitored the election, Correa's exposure on television was more than the double of his rivals. In order to assure a majority in the new Assembly, additional electoral districts were designed in Quito and Guayaquil, two strongholds of Correa. The National Electoral Council refrained stopping the incumbent of using state resources as when Correa made use of army helicopters in his campaign. The Electoral Council did not control how pro-Correa propaganda was broadcasted in the state run media, and forced the leftwing ticket to withdraw a televised add entitled "the little king and his court" alleging that it was offensive to President Correa. The government regulated how the privately owned media reported the campaign, prohibiting it to endorse candidates. As a result, most newspapers refrained from publishing photographs and stories about the closing campaigns acts. ${ }^{57}$ The use of public resources, the abuses of their time in the media, and the lack of mechanism of control led some scholars to use the concept of "competitive authoritarianism" to characterize these left wing populist regimes ${ }^{58}$.

\section{"The People": Between Everyday Politics and Eschatological Salvation}

The people could be conceived as a collection of individuals that participate in political institutions, and simultaneously as a collective body "that establishes these institutions and has a final say on their legitimacy" 59 . These two views of the people -as individual actors of everyday politics, and as the foundation of democratic legitimacygave form to what Margaret Canovan analyzes as the "two phases of democracy". Democracy according to Canovan has a pragmatic and a redemptive phase that often are in tension. From a pragmatic point of view it is a form of government that allows society to cope peacefully with conflicts. It is made of institutions that limit the power of the few who govern, as well as of those who are governed. Yet democracy also has a redemptive phase. "The content of democracy's redemptive promise is power to the people; we, the people, are to take charge of our lives and to decide our own future" 60 .

Margaret Canovan uses the example of Solidarity in Poland to illustrate how the people -conceived simultaneously as the source of sovereign legitimacy, the underdog, and the nation- acted as a mythical collectivity against a regime that grounded its legitimacy as a people's democracy ${ }^{61}$. Yet this was perhaps one exceptional case. Most often actors stage rebellions claiming to speak for the people as a whole, while in fact excluding many from their mythical conceptions. For instance, Ecuador and Bolivia lived through episodes of collective action that redefined the meanings of the terms "the

57 .Carlos DE LA TORRE, 'authoritarian populism in Ecuador' Journal of Democracy, 24 (3), July 2013 (Forthcoming).

58. Kurt Weyland, "Authoritarian Trends in Latin America: Special Threats from the Populist Left", Journal of Democracy, 24 (3), July 2013 (Forthcoming).

59. YACK, "Popular Sovereignty and Nationalism”, p. 519.

60. Margaret Canovan, "Trust the People! Populism and the Two Faces of Democracy", Political Studies, 47/1 (1999), p. 11.

61. Canovan, The People, p. 136. 
people", and "democracy". Between 1997 and 2005 three elected presidents of Ecuador were deposed by what many interpreted as the sovereign people rebelling against illegitimate governments. From 2000 to 2005, Bolivia went through a cycle of insurrections against neoliberalism and corrupt politicians that led scholars to debate whether that nation underwent a revolutionary moment. These rebellions in Bolivia and Ecuador were lived as populist resurrections. "The people" without intermediaries took their political destinies into their own hands. Democratic legitimacy was understood to lie in crowd action where the people directly and without intermediaries expressed its sovereign will. Yet, during these insurrections entire geographical regions such as Bolivia's lowlands or the Ecuadorian coast, where the large cities of Santa Cruz and Guayaquil are located, did not join in. Large segments of the population did not have any voice in how these governments were toppled. Therefore, what for some were populist inherently democratizing insurrections, for others were examples of coup d'état. $^{62}$

Margaret Canovan is well aware of the possible threat of mythical conceptions of the people to democracy. There is a danger that the empty space becomes permanently occupied, and that democracy could be used to justify authoritarian regimes. Ernesto Laclau's influential theory of populism, due to its Schmittian view of the political as the struggle between friend and enemy, as Andrew Arato argues could be used to justified authoritarian regimes. ${ }^{63}$ Laclau, in his book On Populist Reason, argues that populism is synonymous with the political. He contrasts the logics of difference and the logics of equivalence. The first presupposes that "any legitimate demand can be satisfied in a non-antagonistic, administrative way" ${ }^{64}$. Unlike differences that could be resolved with an administrative logic in an individual basis, there are demands that could not be resolved individually and aggregate themselves forming an equivalence chain. Under the logic of equivalence "all the demands in spite of their differential character, tend to aggregate themselves" becoming "fighting demands" that cannot be resolve by the institutional system ${ }^{65}$. The social space splits into two camps: Power and the underdog ${ }^{66}$. The logic of populist articulation is anti-institutional; it is based in the construction of an enemy; and in an equivalential logic that leads to the rupture of the system because individual demands cannot be processed. Under populism, the name of the leader becomes an empty signifier "to which a multiplicity of meanings could be attributed" 67 .

As the pair of terms used by Laclau illustrate, everyday mundane and administrative politics are contrasted to those exceptional moments of populist rupture.

62. For the Ecuadorian case, see: Carlos DE LA TORRE, "Protesta y democracia en Ecuador. La caída de Lucio Gutiérrez", in Margarita LóPEZ MAYA, Nicolás Iñigo CARRERA and Pilar CALVEIRO (eds.), Luchas contrahegemónicas y cambios políticos recientes de América Latina, Buenos Aires, CLACSO, 2008, pp. 197-23. For Bolivia, see: Forrest Hylton and Sinclair ThOMPSON, Revolutionary Horizons. Past and Present in Bolivian Politics, London and New York, Verso, 2007; James DunKERLEY, "Evo Morales, the 'Two Bolivias' and the Third Bolivian Revolution”, Journal of Latin American Studies, 39 (2007), pp. 133-166.

63. Andrew Arato, 'Political Theology and Populism', Social Research 80 (1), 2013.

64. LAClAu, "Populism: What's in a name?", p. 36.

65. Ibid., p. 37.

66. Ibid., p. 43.

67. PANIZZA, "Introduction", p. 19. 
He argues that the division of society into two antagonistic camps is required in order to put an end to exclusionary institutional systems and to forge an alternative order ${ }^{68}$. By giving normative priority to populist rupture, Laclau embraces myths of the revolution as the overhaul of all existing institutions. Reformist institutional improvements are ruled out by normative eschatological constructions of revolutionary politics.

Furet wrote that the French Revolution inaugurated the belief that man was "conscious of the history he was making, but he also knew that he was saved or condemned in and by that history"69. Laclau, true to this view, sees himself as the "Prince Counselor" ". He has become a public intellectual who not only advocates the need for populist ruptures, but who advises Argentinean presidents Ernesto and Cristina Kirchner on how to constitute such a popular subject. He decries that Argentinean relatively strong institutions and complex civil society are impediments to a populist rupture $^{71}$. Because populist rupture entails the destruction of old institutions and the creation of a new institutional order, populist leaders and/or their coalitions might be required to stay in power until their job is done. Laclau's theory of populism might therefore open the door for authoritarian fantasies of power as a possession. Because the political, as for Carl Schmitt, is a struggle between friend and enemy, it is difficult to imagine adversaries who have legitimate institutional spaces. Differently from Chantal Mouffe's adversarial model of the political, where adversaries have legitimate spaces, enemies as in Schmitt's view might need to be manufactured and destroyed.

Chávez, and the opposition, polarized politics as a Manichean struggle between friends and enemies ${ }^{72}$. The logic of equivalency transformed all forms of dissensus into full-blown confrontations between antagonistic camps. Polarization was illustrated during Chávez's illness when half of the population prayed for his death and half for his recovery from cancer. After his death, the government of Maduro continues to stage all political conflicts as Manichean struggles between the patriotic camp embodied in Chávez nowadays deified as a Saint, and the enemies of the nation, the people, and the "process".

\section{Who Speaks for the People?}

When "the people" is invoked, we need to explain who is claiming to speak on its behalf. Politics is a matter of establishing who speaks for the people ${ }^{73}$. The people can speak through insurrections, voting to delegate power to representatives, or by identification between a leader and the led. Rebellions and revolutions give the

68. LaClau, On Populist Reason, p. 122.

69. François FuRET, Interpreting the French Revolution, Cambridge, Cambridge University Press, 1981, p. 52.

70. Vicente PAlermo, "Intelectuales del Príncipe: Intelectuales y Populismo en la Argentina de Hoy", Montevideo (Uruguay), RECSO, Vol. 2, 2011, pp. 81-102.

71. Oswaldo IZAETA, "Democracia y dramatización del conflicto en la Argentina kirchnerista (20032011)”, in Isidoro ChrERESKY (ed.), ¿Qué democracia en América Latina?, Buenos Aires, CLACSO and Promoteo, 2012, p. 285.

72. Mireya Lozada (ed.), Polarización Social y Política en Venezuela y Otros Países. Experiencias y Desafios, Temas de Formación Sociopolítica, n49, Caracas, Centro Gumilla, 2011.

73. FURET, Interpreting the French Revolution, p. 48. 
impression that "the people comes into existence through collective action, somehow emerging as both the director and actor of its own destiny" 74 . During extraordinary events the people acquire a face and a voice, and are given an imaginary social cohesion. Doubts about how a group of individuals could become a unitary actor with a single voice are suspended. It is imagined that the people speak by directly taking over the symbols of state power that excluded them, while simultaneously creating new symbols and institutions.

Even if we accept that the people during extraordinary events can temporarily speak in unison to say "enough", their collective action does not solve the problem of what happens after the event. "How can (the people) retain a recognizable form, and how to hear its disappeared voice once the event is over and done?"75. Liberal and populist give alternative answers to the question of how does the people speak when it is not insurrecting. Representation is based on a constitutive gap between "the people as the legitimate sovereign, in its unity in principle, and the people as an existing society, in its actual complexity" "76. How to preserve the complexity of society while appealing to the unity of the sovereign people? Mediated forms of representation accept the complexity and diversity of the people in an existing society, whereas populist representation seeks its unity in the embodiment of the people in the figure or in the name of a leader.

Mediated forms of representation are based on the principle of non-identity between representatives and their constituency. A collectivity "authorizes some individuals to speak for it, and eventually to commit the collectivity to what the representative decides"77. Representatives, for their part, are accountable for their actions. Liberal representation is based on as series of mediations such as constitutional restrains, divisions of powers, and check and balances.

Populism is a response to the crises of mediated representation. Populists discourse portraits mediations and restrains as impediments that the elite uses to exclude the people. Populists view elections as the "decisive moment of the representative contract", ${ }^{78}$. Elections are understood as processes of popular authorization that exclude any element of accountability. For example, after winning the election of 1949, General Juan Perón said, "we have given the people the opportunity to choose, in the cleanest elections in the history of Argentina, between us and our opponents. The people have elected us, so the problem is resolved. What we want is now done in the republic of Argentina"79.

Populist representation is based on the "merging and full identity between a representative and those who seek representation" ${ }^{\circ 0}$. Because the leader claims to be

74. RosanVallon, Democracy Past and Future, p. 96.

75. Ibid., p. 97.

76. Ibid., p. 91.

77. Guillermo O’DonNell, “Delegative Democracy”, Journal of Democracy, 5/1 (1994), p. 61.

78. Enrique Peruzzotti, "Populism in Democratic Times: Populism, Representative Democracy, and the Debate on Democratic Deepening.", in Carlos DE LA TORRE and Cynthia ARNSON (eds.), Latin American Populism in the Twenty First Century, Baltimore and Washington, The Johns Hopkins University and the Woodrow Wilson Center Press, 2013, p. 98.

79. Ibid., p. 97.

80. David PlOTKE, "Representation is Democracy," Constellations, 4:1 (April 1997), p. 28. 
like the people he knows their interest and can incarnate their will. Under populist discourse the people share an identity, interests, and form a collective body "which is able to express this will and take decisions" $"$. The leader perceives himself not as an ordinary politicians elected in a succession of temporarily elected officials. He rather sees himself as the incarnation of the people ${ }^{82}$. After winning the 2009 presidential elections, Rafael Correa asserted: "Ecuador voted for itself". This way, he claims to embody the will of all Ecuadorians. In several speeches he reiterated to be leading Ecuador's second independence. Because of the immensity of his mission, he has faced the opposition of traditional parties, bankers, the privately owned media, and what he describes as the leadership of corporatist social movements such as teachers, students, and indigenous organizations. He has labelled ecologists and the indigenous movements as the infantile leftwing that serves the interests of the right. His administration has charged over 200 peasant and indigenous activists as terrorists.

As Benjamín Arditi writes, the fantasy of the unity of the people and of their merging with the leader "opens the door for a perception of the exercise of political power as a possession rather than as occupancy, which, in turn, is conducive to a patrimonial use of state resources" ${ }^{\$ 3}$. Citizens are transformed into grateful masses that accept resources distributed from the top down ${ }^{84}$. Ethnographic studies show that programs of social distribution in Ecuador, for example, are used to build beneficiaries who feel personally obliged to president Correa. Anthropologist Luis Tuazo shows that the recipients of the bonus for human development that allocates 35 dollars to single mothers, the elderly, the disabled, and the poorest feel that they need to reciprocate the government. An indigenous woman from Tixan, in the Province of Chimborazo, reported: "Today I am grateful to God and to President Correa. I have the cash transfer to buy food, pay for electricity, and can buy a little something for my kids". Another woman corroborated: "Thanks to the President I get 35 dollars". As one respondent summarized the feelings of reciprocity, "the government takes care of us, we have to be grateful" $" 85$.

Politicians are not the only actors who claim to be the voice or the spokesmen of the people. Social movement activists also claim to speak for them, and to be their representatives, and even their embodiment. In Bolivia for example, strong social movements curtail Morales' attempts to be the voice of the unitary people, forcing him to negotiate and even to reverse policies. Participation is mostly bottom up, and the government relies on the mobilization of social movements in conflicts with the

81. Koen Abts and Stefan Rummens, "Populism versus Democracy," Political Studies, 55 (2007), p. 409.

82. Enrique Peruzzotti, "Populismo y Representación Democrática", in Carlos DE LA TORRE and Enrique Peruzzotti (eds.), El retorno del pueblo. El populismo y nuevas democracias en América Latina, Quito, FLACSO, 2008, p. 110.

83. Benjamín ARDITI, Politics at the Edge of Liberalism, Edinburgh, Edinburgh University Press, 2007, p. 83.

84. Ibid., p. 86.

85. Luis Alberto TuAZA, "La relación del gobierno de Rafael Correa y las bases indígenas: políticas públicas en el medio rural", Ecuador Debate, 83 (August 2011), p. 145. 
opposition $^{86}$. Evo Morales came to power at the peak of indigenous led popular protest against neoliberalism and pacted democracy. His party is the political instrument of strong social movements. Participation in Bolivia is grounded in communitarian traditions where all participate and deliberate until a decision is made. Leaders at all levels are accountable to their social base. Hence, participation under Morales is more bottom-up than in Venezuela or Ecuador. Organizations of the subaltern have forced the government to reverse policies such as the increase of gasoline prices and wage restraints in 2011.

\section{Conclusions}

This paper showed the ambiguities of the highly emotional terms of the people and populism. These concepts, as shown in this article, oscillate between poles: threat and promise, danger and redemption. The article illustrated how constructions of the people continue to appeal to notions of the dangerous mobs. It illustrates how elites appropriate the voice of the people to legitimate their rule as the rightful interpreters.

Activists, and dissenters, including populist politicians challenge the rule of elites, claim to speak for the people. Their interventions aim to disrupt the normalcy of things, and of the status quo. Workers, for instance, "spoke in order to say that they were not those Others, those 'barbarians' that bourgeois discourse denounced" Dissenters destabilize the common sense that gives authority to the voices of some people of the community, and that recognizes some issues as valid and important. A dissensus is "a dispute over what is given and about the frame within which we see something as given" 88 . It is "a practice of disidentification whereby the people refuse to accept the place -often of the excluded underdog—assigned to them" ${ }^{, 89}$.

Challenges to the exclusion of those considered having no voice, and to those whose issues are interpreted as irrelevant or particularistic are of course potentially democratizing. This type of interventions is what gives democratic credentials to populist and social movement activists. The question is how these demands will be processed. Will they entail a deepening of democracy maintaining its representative fabric, mediations, checks and balances, which allow for pluralism and contestation? Or would they lead to Jacobin symbolic appropriations of the people's will ${ }^{90}$, and to attempts to occupy the open space of democracy?

86. Eduardo CóRdova, "Movimientos Sociales en Bolivia. Acción Colectiva y Democracia en Tiempos de Cambio", in Martín TANAKA and Francine JÁCOME (eds.), Desafíos de la Gobernabilidad Democrática. Reformas Político-Institucionales y Movimientos Sociales en la Región Andina, Lima, IEP, 2010, pp. 175-213; Fernando MAYORGA, "Movimientos Sociales y Participación Política en Bolivia", in Isidoro CHERESKY (ed.), Ciudadanía y Legitimidad Democrática en América Latina, Buenos Aires, CLACSO and Promoteo, 2011, pp. 19-43.

87. RANCIÈRE, Staging the People, p. 22.

88. RANCIÈRE, Dissensus, p. 69.

89. ARDITI, Politics at the Edge of Liberalism, pp. 78-79.

90. FURET, Interpreting the French Revolution, p. 73. 